Large carnivores and small games use from the Early Aurignacian of La Quina aval (Charente, France) (V. Dujardin excavations)

Grands carnivores et mésofaune de l'Aurignacien ancien à La Quina aval

(Charente, France) (fouilles V. Dujardin)

Jean-Baptiste Mallye, Marie-Cécile Soulier and Véronique Laroulandie

(c) OpenEdition

Journals

Electronic version

URL: http://journals.openedition.org/paleo/2865

DOI: $10.4000 /$ paleo.2865

ISSN: 2101-0420

Publisher

SAMRA

Printed version

Date of publication: 15 December 2013

Number of pages: $235-248$

ISSN: $1145-3370$

Electronic reference

Jean-Baptiste Mallye, Marie-Cécile Soulier and Véronique Laroulandie, «Large carnivores and small games use from the Early Aurignacian of La Quina aval (Charente, France) (V. Dujardin excavations) », PALEO [Online], 24 | 2013, Online since 15 September 2015, connection on 07 July 2020. URL : http:// journals.openedition.org/paleo/2865; DOI : https://doi.org/10.4000/paleo.2865

This text was automatically generated on 7 July 2020.

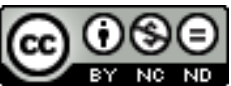

PALEO est mis à disposition selon les termes de la licence Creative Commons Attribution - Pas d'Utilisation Commerciale - Pas de Modification 4.0 International. 


\title{
Large carnivores and small games use from the Early Aurignacian of La Quina aval (Charente, France) (V. Dujardin excavations)
}

\author{
Grands carnivores et mésofaune de l'Aurignacien ancien à La Quina aval \\ (Charente, France) (fouilles V. Dujardin)
}

Jean-Baptiste Mallye, Marie-Cécile Soulier and Véronique Laroulandie

We wish to thank Véronique Dujardin for giving us access to the bone series from La Quina aval and for supplying all the data concerning her excavations. We also thank Françoise Delpech and Jean-François Tournepiche for their very constructive comments which improved the first version of this article.

\section{1 - Introduction}

1 The main evidence of the exploitation of the animal world by prehistoric groups comes from studies focusing on ungulates, as the latter dominate the food resource supply of prehistoric hunters. However, evidence of small game and carnivore processing is scant. Although archaeofaunas may comprise large quantities of small animal remains, their contribution to the meat intake is marginal compared to that of ungulates. Nonetheless, the study of these remains is fundamental in order to understand why these low-return animals (in terms of processing 'costs' versus energy return) were introduced into hunter-gatherer diets. In the same way, it is essential to bear in mind that a more varied exploitation of these resources may have been practiced and that these remains may have been used for utilitarian or symbolic purposes.

2 Several short notes in different publications refer to the carnivore and leporid remains from the excavations carried out by V. Dujardin in the Aurignacian layers from the site of La Quina aval (Dujardin et al. 1999; Dujardin 2001, 2005, 2006; Dujardin \& Kervazo 
2010). In these articles, where the fauna is presented in a concise manner, the presence of the wolf, the fox, and the Cave Lion is mentioned and the leporids are exclusively represented by the hare. Although the reindeer bones bear numerous butchery marks, there is no mention of such marks on carnivore and hare remains. This absence of marks has been interpreted as evidence of a natural origin for these species at the site. In addition, many decorative elements made on fox, wolf and hyena teeth were found during both the early excavations conducted by Dr. Henri-Martin (Henri-Martin 1925, 1930) and by his daughter Germaine (Granger \& Lévêque 1997) and during recent surveys by Dujardin (Dujardin et al. 1999). Moreover, Henri-Martin (1930) mentions six bone fragments transformed into tools, including one bird bone, one hare and three fox bones. It was not possible to provide specific identification of the latter, given the extent of transformation. These objects prove that these animals were used for utilitarian (domestic tools) or ornamental purposes, through the fabrication of decorative elements. Currently, no data document the integration of these animals in the food supply of the Aurignacians from La Quina aval.

This observation may be extended to a wider spatial-temporal scale. The exploitation of carnivores is often reduced to the acquisition of prestigious elements (teeth, fur) or hunting trophies (Bouchud 1951; Henri-Martin 1930). For example, in Solutrean sites, the lack of data relating to the exploitation of carnivores for non-technical purposes supports the hypothesis of the procurement of these remains (teeth and bones) from dead animals (Chauvière \& Castel 2004).

Over the past years, the number of archaeological cases of carnivore, and more generally, small game exploitation, has been growing steadily, for increasingly earlier periods (Auguste 1995, 2003; Blasco 2008; Blasco \& Fernández-Peris 2009; Blasco, Fernandez-Péris \& Rosell 2010a and b; Bratlund 1999a and 1999b; Cochard et al. 2012; David 1997, 2004; Jaubert et al. 2008; Mallye 2007; Morin \& Laroulandie 2012; Münzel \& Conard 2004a, 2004b; Peresani et al. 2011; Rosendhal \& Draga 2004; Soulier \& Mallye 2012; Stiner 1994; Yravedra 2007).

We therefore decided to reexamine this collection in order to quantify the number of remains from the different taxa and to identify the origin of these remains. The results presented here only concern the faunal material from the V. Dujardin excavations; all of the remains studied come from the upper levels and are remnants of Aurignacian layers (early Aurignacian).

\section{2 - The La Quina aval site}

The site of La Quina aval (trench Y-Z) is located $200 \mathrm{~m}$ southwest of the eponymous site La Quina, on the townland of Gardes-Pontaroux in the department of Charente in France (fig. 1). It was discovered at the end of the 19th century (Chauvet 1896) and was excavated from 1906 to 1936 by Doctor Henri-Martin, then from 1953 to 1971 by his daughter Germaine. In 1994, 1995 and 1998, V. Dujardin carried out a reevaluation of the site in order to define the stratigraphy, the deposition of the sediments and the archeological contents. A limited excavation was conducted at that time $(2.5 \mathrm{~m} 2)$, the finds were spatially recorded and the sediment was wet-sieved with a $1 \mathrm{~mm}$ mesh 
(Dujardin 2005). After this campaign, the stratigraphy revealed several levels, grouped into three complexes from the base to the top:

- the lower levels correspond to alluvial sediments containing pre-Mousterian industry elements in secondary position;

- the intermediary levels at the base of the alluvial levels and at the top of the scree correspond to the collapse of the ancient rock shelter. These levels contained little archaeological material but a dozen Chatelperronian points were recovered (Dujardin 2001). An AMS date on bone yielded an age of 35,950+/-450 BP [OxA - 10261 (Lyon-1367)];

- the upper levels are made up of remnants of Aurignacian layers. These layers contain abundant ochre, lithic and faunal material (bones, teeth and burnt bone), bone industry and decorative elements (Dujardin 2001; Dupont 2001). On the basis of the typo-technological study, the lithic industry can be ascribed to the early Aurignacian (Dujardin 2005). An AMS date on bone from the base of this complex provided an age of 32,650 \pm 850 BP [(OxA-6147 (Lyon-256)].

Figure 1- La Quina aval: Geographic location of the site (Gardes-le- Pontaroux, Charente).

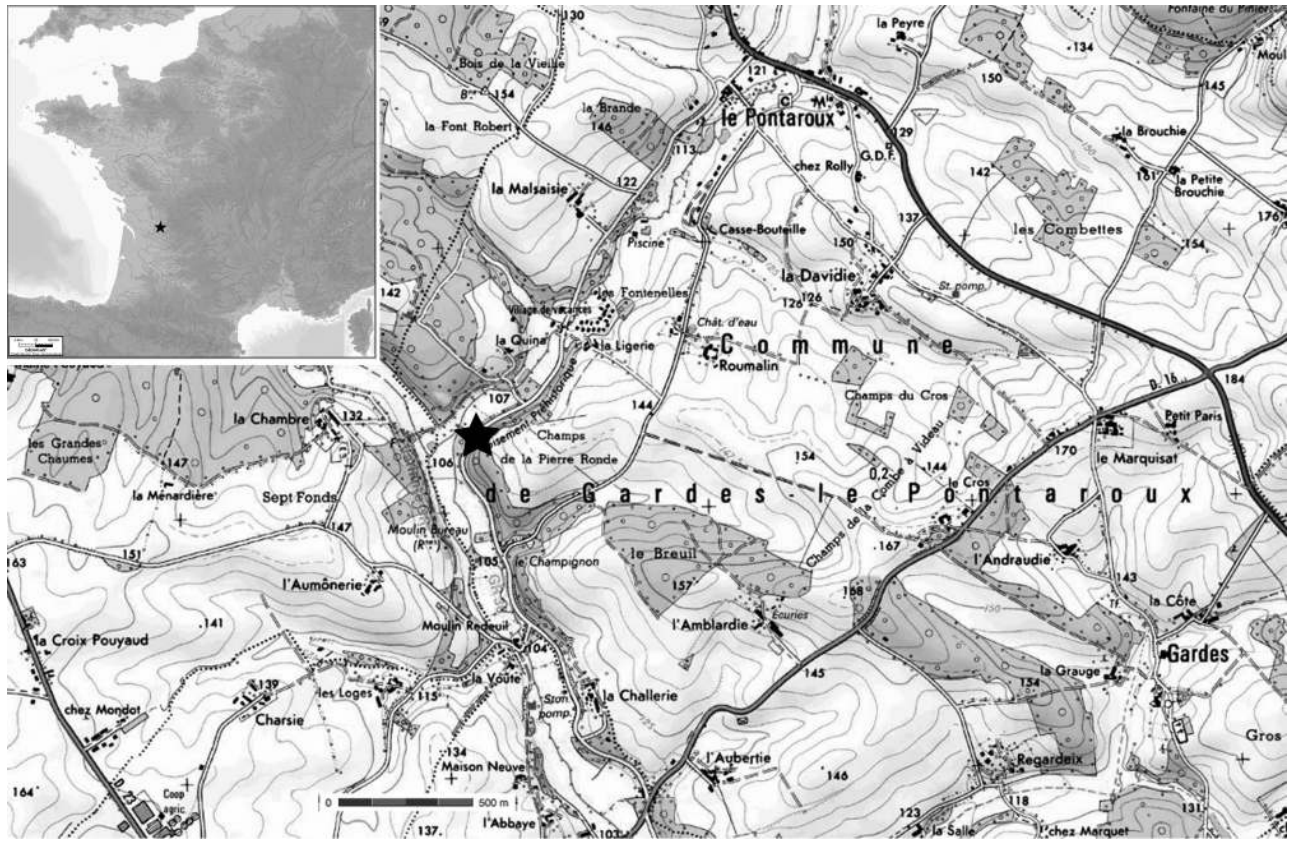

7 The early excavations also yielded four human bone remains from four individuals which have been described in the literature. On the basis of the morphometric analysis of these remains, they can be ascribed to anatomically modern humans.

\section{3 - Material and method}

8 All the material issued from the Dujardin excavations was reexamined then identified using the osteologcial collection from the PACEA laboratory. The specific identifications (for example, Lepus timidus vs europaeus) were carried out on the basis of published osteometric references (Morel \& Müller 1997). The seminal work of Poplin (1976), but also that of Koby (1959a), or more recently the work of Altuna (2004) or Monchot \& Gendron (2010) was used for differentiating these two species. The decorative elements were not restudied here, but were nonetheless taken into 
consideration for the interpretative analysis. All the taphonomic elements likely to provide information on the factors determining the presence of the remains at the site (traces of human and/or animal predation) were recorded for all the pieces. In this way, each piece was observed with a magnifying lens (magnification x10) and a Leica Z16 APO macroscope (magnification x80).

9 The location and the orientation of the cut marks were compared to those of current reference collections compiled for small carnivores (Mallye 2011; Val \& Mallye 2011) or leporids (Lloveras, Moreno Garcia \& Nadal 2009) and other taxa (Binford 1981), in order to interpret the aims of processing. Comparisons with ethnoarchaeological and archaeolgocial data relating to the consumption of small game were also taken into account (Vigne et al. 1981; Vigne \& Marinval-Vigne 1983; Henshilwood 1997; Medina, Teta \& Rivero 2012).

\section{4 - Results}

\section{1 - Faunal spectrum}

Altogether, 115 small game and large carnivore remains were reexamined. All the taxa (tab. 1) described in previous studies were identified (Dujardin 2001, 2005, 2006; Dujardin, Kervazo 2010; Dujardin et al. 1999), apart from the cave lion. As is the case for this type of material in many archaeological sites, the number of remains and the number of individuals for each taxon is relatively small in comparison with the number of ungulate remains and individuals (tab. 1). There are eleven wolf and hare remains, while the only European polecat remain is the cotyloid cavity of a scapula. Vixen remains are much more abundant and account for more than three-quarters of the studied pieces.

Given the bone measurements (see Altuna 2004; Koby 1959a; Poplin 1976), the Vulpes remains are issued from both known species in Western Europe; the Red Fox (Vulpes vulpes) and the Arctic Fox or Isatis (Alopex lagopus) (tab. 2). This identification was limited by the high fragmentation rate of the bone remains. As most of the osteometric reference frameworks are made up of whole bones (eg. Koby 1959a or Monchot \& Gendron 2010), they were difficult to apply to fragmentary remains. We nonetheless identified a Red Fox and an Isatis on the basis of the second metatarsal (tab. 2). No specific determination was conducted for the hare as no diagnostic elements were present (ie., incisors). Given the fragmentary state of the material, we could not apply Koby's metric data $(1959 b, 1960)$ to the post-cranial skeleton. Lastly, the Snowy Owl is represented by three phalanges, including two claws from the third finger and a penultimate. The proximal height of these two claws is identical $(11.2 \mathrm{~mm})$. These claws are symmetrical and may come from the same specimen, which would be a female according to Gourichon's measurements (1994). 
Table 1- La Quina aval: Number of identified remains per taxon and minimum number of individuals in brackets (Early Aurignacian). Ungulate data derived from Soulier (2013).

\begin{tabular}{|l|r|}
\cline { 2 - 2 } \multicolumn{1}{c|}{} & NISP (NMI) \\
\hline Cheval & $107(3)$ \\
Bovinés & $27(2)$ \\
Renne & $2987(22)$ \\
Cerf & $2(1)$ \\
Loup & $11(1)$ \\
Renard / Isatis & $84(2)$ \\
Putois & $1(1)$ \\
Lièvre & $11(1)$ \\
Harfang & $3(1)$ \\
Mésofaune indét. & 5 \\
Ongulés 1/2 & 4 \\
Ongulés 2 & 502 \\
Ongulés 2/3 & 47 \\
Ongulés 3/4 & 66 \\
Ongulés 5 & 4 \\
Indéterminés & 1634 \\
\hline Total & $\mathbf{5 4 9 5}$ \\
\hline
\end{tabular}

Table 2 - La Quina aval: Measurements of fox bones with specific identification. LT: total length, DAP. antero- posterior diameter, DT: transversal diameter, p: proximal, d: distal

\begin{tabular}{|llrrrrrc|}
\hline \multicolumn{1}{|c}{ Référence } & \multicolumn{1}{c}{ Anatomie } & LT & DAP p & DT p & DAP d & DT d & Détermination spécifique \\
\hline E8-226 & Radius & & & & 7,1 & 12,8 & Alopex lagopus \\
C4-25 & Tibia & & & & 9,5 & 13,2 & Alopex lagopus \\
Qav 11 436 & Ulna & & 12,2 & & & & Alopex lagopus \\
C4-84 & Métatarsien II & 51,8 & & 5,2 & 5,2 & 6 & Vulpes vulpes \\
C4-31 & Métatarsien III & 56,7 & 8,1 & 5,9 & 5,4 & 4,8 & Vulpes vulpes \\
C4-1850 & Métatarsien V & & 6,6 & 6,9 & & & Alopex lagopus ? \\
E8-5690 & Métatarsien III & & 7,6 & 4,5 & & & Alopex lagopus ? \\
C4-1891 & Métacarpien V & & 5,2 & 5,8 & & & Alopex lagopus ? \\
C5-993 & Métatarsien II & 59,6 & & 6,5 & 6,3 & 7,4 & Vulpes vulpes \\
C4 & Calcanéum & 28,3 & & & & & Vulpes vulpes/Alopex lagopus \\
\hline
\end{tabular}

\section{2 - Traces of human activity}

12 Apart from the polecat, all of the taxa bear butchery marks (tab. 3). They are present on six wolf remains, sixteen fox remains, five hare remains, two indeterminate remains and a Snowy Owl bone, or more than a quarter of the analyzed remains. Most of the marks are made up of cut marks and several remains show traces of burning.

13 The presence of ochre on bone and dental surfaces is noteworthy. During the excavation, ochre was so abundant in this sedimentary complex that the archaeological remains were stained (Dujardin 2005). The presence of ochre on faunal remains cannot therefore be directly interpreted as a deliberate anthropogenic transformation. 
However, the fact that ochre imprints were found on all the remains (ungulates and small game) suggests that all the bones were treated identically.

Figure 2 - La Quina aval: Wolf remains. A: Left mandible with cut marks on lingual face. B: Lower right canine with detail of scraping marks on the root. C: First phalange with heat marks on the dorsal face. D: Right calcaneus, the distal part is missing; note the heat marks on the edge. E: First phalange with ochre and cut marks on the plantar face. Scale bar is $1 \mathrm{~cm}$.
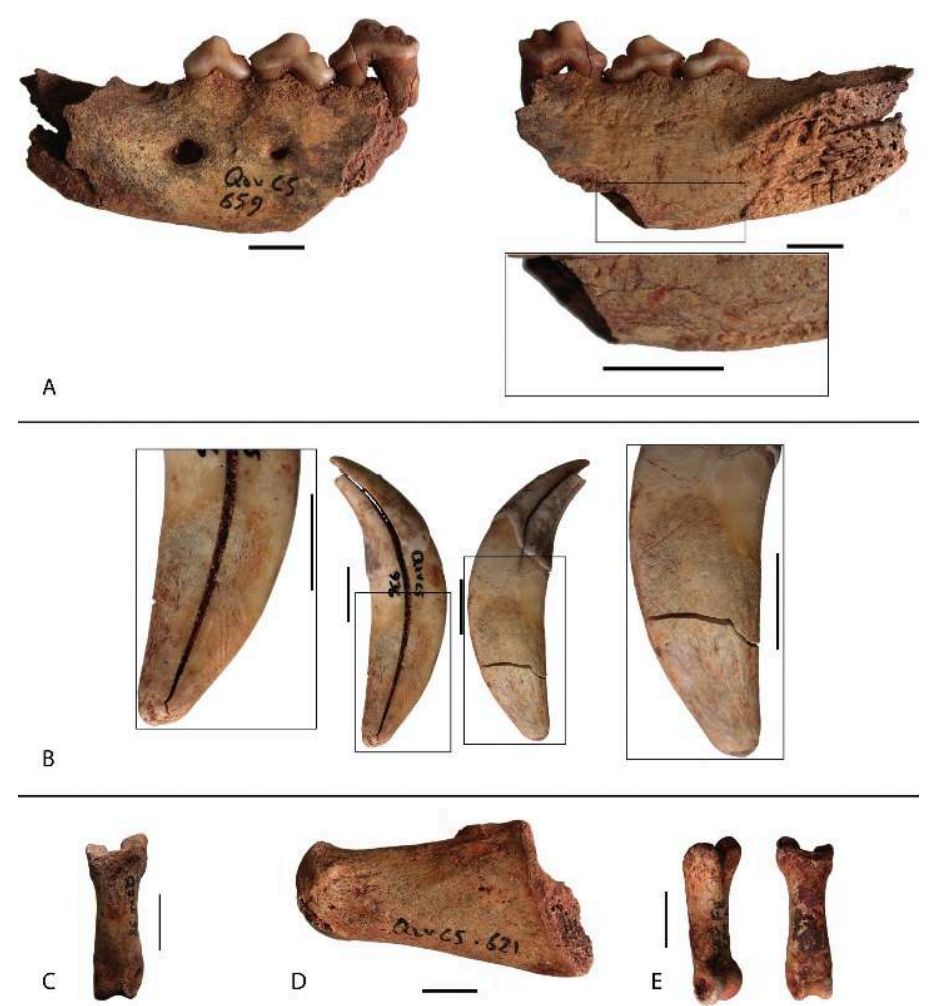
Table 3 - La Quina aval: Cut mark locations and interpretation of butchering activities. Location of marks: Ant: Anterior. Dist: Distal. Dors: Dorsal (caudal). Lat.: Lateral. Ling.: Lingual. Med.: Medial. Médi.: Median. Mes. : Mesial. Palm.: Palmar. Post.: Posterior. Prox: Proximal. Vent.: Ventral. Vest: Vestibular. Orientation: Long. Longitudinal. Trans: Transverse. Obli.: Oblique.

\begin{tabular}{|c|c|c|c|c|c|}
\hline Identifiant & Taxon & Anatomic & Position & Orientation & Activité(s) \\
\hline Qav-E8-20200 & Lepussp. & Fémur & Prox. Ant. & Trans. & Désarticulation \\
\hline Qav-1D8-373 & Lepussp. & Humérus & Prox. Ant. & Trans. & Désarticulation \\
\hline Qav-C5-1018a & Lepus sp. & Radius & Prox. Ant. & Trans. & Désarticulation \\
\hline Quv-C5-416b & Lepussp. & Rutdius & Disl. Ant. & Truns. & $\begin{array}{l}\text { Dépouillement/ } \\
\text { désarticulation }\end{array}$ \\
\hline Qav-F8-111 & Lepussp. & Tibia & Med. Medi. & Trans. & Décharnement \\
\hline Qav-C5-621 & Canis lupus & Calcanéum & Med. Medi. & Obli. & Dépouillement \\
\hline Qav-C5-659 & Canis lupus & Mandibule & Mes. Ling. & Obli. & Décharnement \\
\hline Qav-C5-659 & Canis lupus & Mandibule & Mes. Vest. & Obli. & Décharnement \\
\hline Qav-F8-225B & Canis lupus & Phalange 1 & Prox. Palm. & Trans. & Dépouillement \\
\hline Qav-D8-277 & Canis lupus & Phalange 1 & Dist. Dors. & Obli. & Dépouillement \\
\hline Qav-C5-936 & Canis lupus & Canine inférieure & Racine & Obli.+Long. & Utilitaire \\
\hline Qav-C5-416c & $\begin{array}{l}\text { Mésofaune } \\
\text { indét. }\end{array}$ & Côte & Med. Lat. & Trans. & Décharnement \\
\hline Qav-C5-618 & $\begin{array}{l}\text { Mésofaune } \\
\text { indél. }\end{array}$ & Côte & Med. Lat. & Trans. & Décharnement \\
\hline Qav-C5-852 & Vulpinae & Prémaxillaire & Lat. & Trans. & Dépouillement \\
\hline Qav-C5-416b & Vulpinae & Condyle occipital & Vent. & Trans. & Désarticulation \\
\hline Qav-C5-838 & Vulpinae & Mandibule & Med. Vest. & Obli. & Dépouillement \\
\hline Qav-E8-1925 & Vulpinale & Métacarpien 1 & Med. Lat. & Trans. & Dépouillement \\
\hline Qav-C5-46 & Vulpinae & Métapode & Dist. Dors. & Obli. & Dépouillement \\
\hline Quv-C5-993 & Vulpinae & Mélatarsien II & $\begin{array}{l}\text { Prox. Palm et } \\
\text { Prox. Dors. }\end{array}$ & Long,+Obli. & Dépouillement \\
\hline Qav-C4-1850 & Vulpinae & Métatarsien V & Med. Palm. & Obli. & Dépouillement \\
\hline Qav-C5-1017 & Vulpinae & Métatarsien V & Dist. Med. & Obli. & Dépouillement \\
\hline Qav-C4-65 & Vulpinae & Phalange 1 & Med. Dors & Trans. & Dépouillement \\
\hline Qav-E8-226 & Vulpinae & Radius & Dist. Post. & Long. & Décharnement \\
\hline Qav-C4 & Vulpinae & Calcanéum & Med. & Obli. & Dépouillement \\
\hline Qav-C5-788 & Vulpince & Calcanéum & Med. & Obli. & Dépouillement \\
\hline Qav-C5-310 & Vulpinae & Tibia & Med. Lat.+Post. & Obli+Trans. & Décharnement \\
\hline Qav-C4-82 & Vulpinae & Tibia & Prox. Post-Medi. & Trans. & $\begin{array}{l}\text { Désarticulation } \\
\text { Décharnement }\end{array}$ \\
\hline Quv-C5-330 & Vulpinae & Tibia & Mcd. Ant. & Trans. & Décharnement \\
\hline Qav-D5-15 & Vulpinae & $\begin{array}{l}3 \text { ème prémolaire } \\
\text { supérieure }\end{array}$ & Mes. Vest. & Trans.+Obli. & Inconnue \\
\hline Qav-C4-50 & Bubo scandiace & Griffe & Prox. & Trans. & Désarticulation \\
\hline
\end{tabular}

\section{a -The Wolf}

As far as the wolf is concerned (fig. 2 and tab. 3), short, oblique cut marks are located on the lower side of the horizontal branch of the mandible, on the vestibular side. Other short and oblique cut marks are present on the phalanges and the calcaneus. Depending on their location and orientation these cut marks attest to carcass skinning. Other short and oblique cut marks (fig. 2) were observed on the lingual side of the mandible, near the symphyseal surface. These could result from the removal of the tongue (also noted by Binford 1981 for the reindeer). Lastly, scraping marks were observed on the apex of the root of a lower canine. These marks are not linked to food requirements but could correspond to the preparation of the tooth with a view to using it as a decorative element. The contextual data validate this hypothesis as the presence of ornamental elements in early excavations confirms the recovery of teeth for this purpose. Moreover, traces of burning were observed on the distal part of the calcaneus, as well as on a triquetrum (pyramidal bone), a pisiform and on the dorsal side of a phalanx. These marks can be considered as the "distal burning" previously described on small game (Vigne et al. 1981; Vigne \& Marinval-Vigne 1983). They result from the cooking of skeletal parts near a source of heat. A whole wolf carcass may thus have been brought to the site, skinned and then cooked. In this way, for early Aurignacian hunter-gatherers, this carnivore appears to have been part of their food (meat consumption) and utilitarian sphere (teeth, removal and possible use of the skin). 


\section{b - The Fox} carcasses were brought to the site by Aurignacians. Certain bones are missing from the corpus, but this may be related to the limited extension of the excavation. The cut marks are all linked to cutting (fig. 4 and tab. 3). They are present on the muzzle (premaxilla and mandible), the tibia, radius, metapodial bones and certain phalanges. In comparison to reference collections (Mallye 2007, 2011; Val \& Mallye 2012), skinning, defleshing and quartering can be brought to light. It is difficult to gauge whether or not marrow was extracted from the long bones as only a distal tibia portion presents edges characteristic of fractures on green bones (sensu Villa \& Mahieu 1991). Other cut marks were observed on the neck and the crown of a premolar. The cut marks follow the mesio-distal orientation of the tooth and their number on the crown may indicate a repeated gesture from the front to the back. These marks have not been described in reference collections and are difficult to interpret in terms of butchery practices. Carcasses were thus intensively processed from the skinning stage until meat, and probably marrow consumption. However, the capture techniques practiced by hunters remain largely unknown, due to the absence of direct evidence.

Numerous previously described ornamental elements (Granger \& Lévêque 1997; Dujardin et al. 1999) indicate that small carnivore teeth were used as raw materials, like at many Aurignacian sites. The consumption of the flesh of these animals has also been demonstrated, but no evidence of Aurignacian fox fur preparation and conservation has been revealed. The site has not yielded criteria pointing to fur and leather making activities (eg. Cochard \& Brugal 2004; Mallye 2011; Soulier \& Mallye 2011). However, the presence of a large quantity of oxides (ochre) at the site could be evidence of the processing and/or conservation of skins and/or furs by prehistoric groups. Furthermore, a certain number of bone tools (lissoirs, awls) were discovered in the early collections and during the V. Dujardin excavations (Dujardin 2006). Thus, the processing of carnivore and ungulate skins appears to be plausible.

\section{c - The Hare}

17 Cut marks (tab. 3) were observed on the different hare long bones (humerus, radius and tibia). According to the results obtained by Lloveras and collaborators (2009), these marks attest to the quartering of the different segments and/or the removal of the flesh with a view to consuming it. Due to the low number of remains, it is not possible to provide further documentation of the operative schema.

\section{d - The Snowy Owl}

Lastly, cut marks were identified on the joint of a Snowy Owl claw (fig. 5). This mark is characteristic of the dismemberment of the claw when the cutting edge is transversal to the long axis (Laroulandie 2000 - p. 129, fig. 34e). 
Figure 3 - La Quina aval: Body part representation of the fox in the Dujardin collection. In white: missing remains. Light grey, $\mathrm{MNI}=1$. Dark grey, $\mathrm{MNI}=2$. Cut mark locations are represented by the small black triangle.

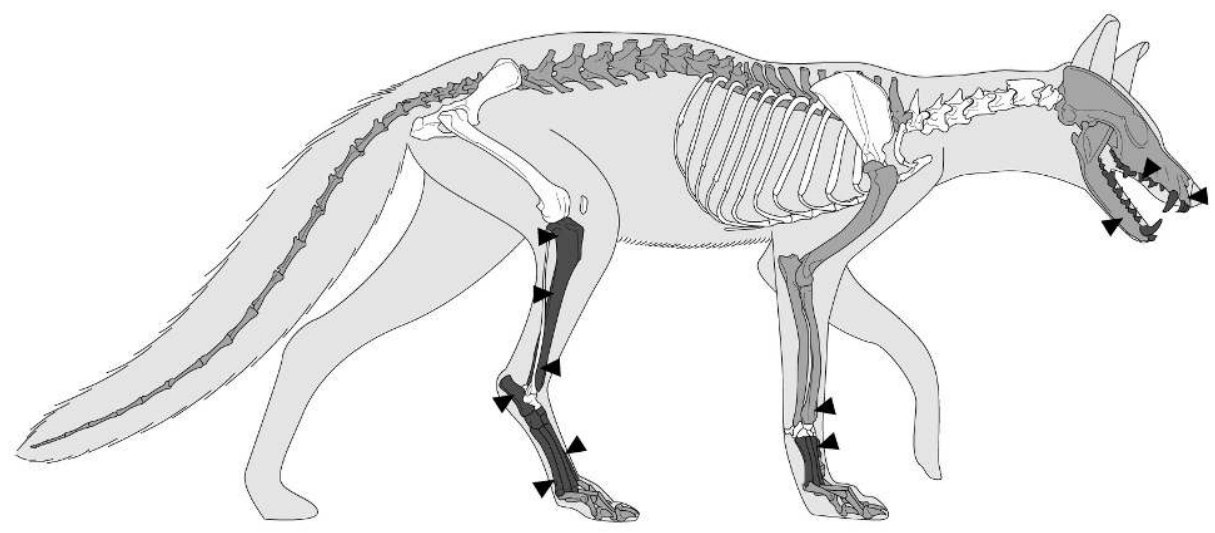

Figure 4 - La Quina aval" Fox remains. A: right mandible, note the cut mark on the vestibular face. 8: tooth fragment (premolar), note the deep cut mark at the limit between the root and the neck and the numerous fine striations on the tooth crown. C: first phalange with impact pit on the dorsal face. E: metapodial with skinning marks. F: first metacarpal with skinning marks. G: Right radius with numerous cut marks resulting from quartering and skinning activities. 1.- Left premaxilla with skinning marks. Scale bar is $1 \mathrm{~cm}$.

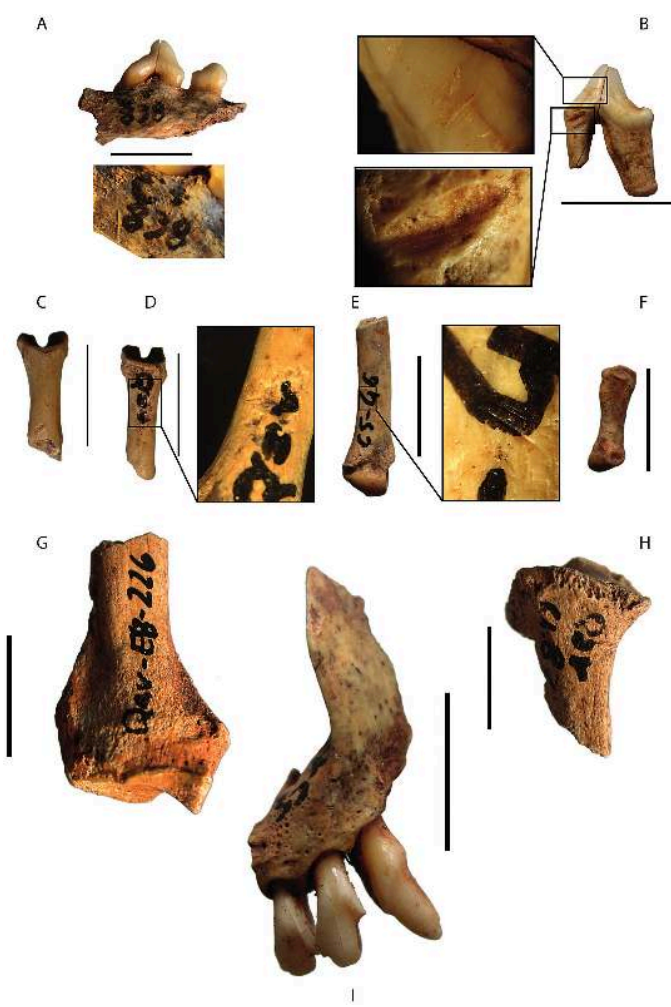


Figure 5 - La Quina aval: The three snowy owl remains and cut mark. Scale bar is $1 \mathrm{~cm}$, unless stated otherwise.
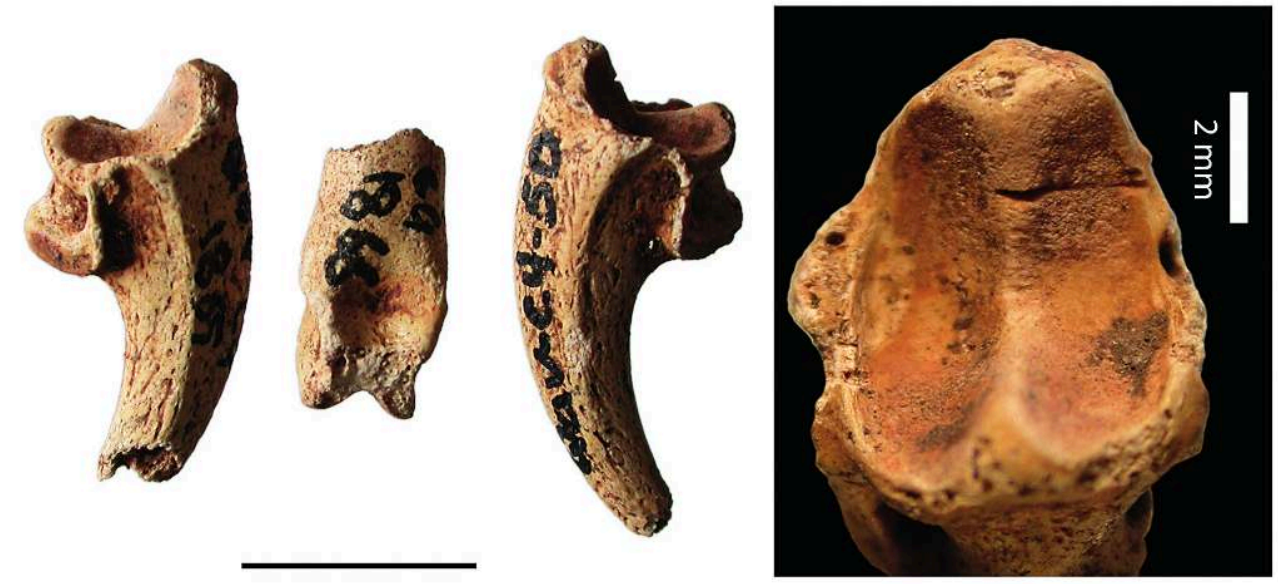

Figure 6 - La Quina aval: Game status in the Aurignacian hunter-gather economy.

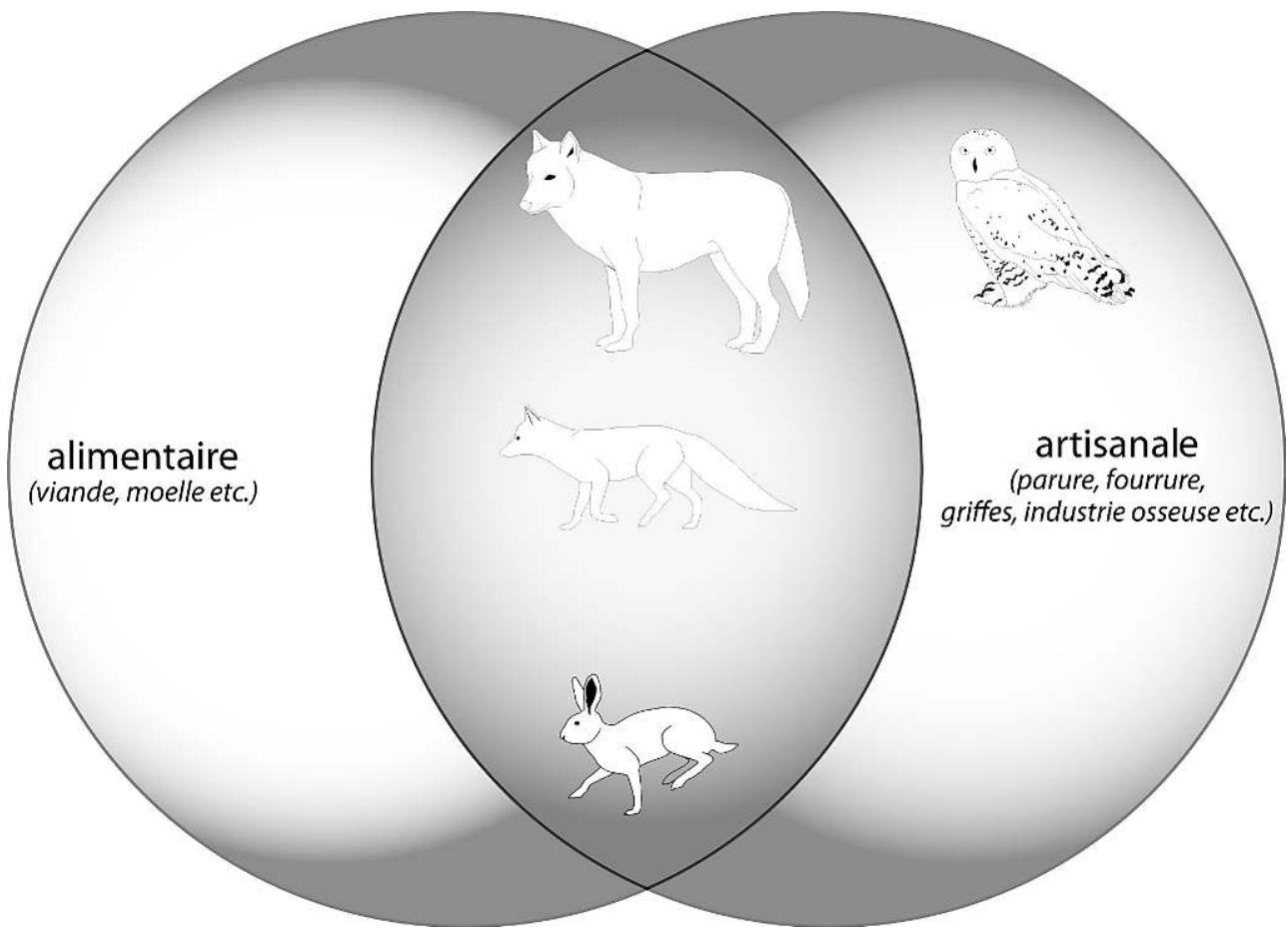

\section{5 - Discussion}

The reexamination of this series has enabled us to establish a faunal spectrum and to provide quantitative data on the large carnivores and small fauna from the site of $\mathrm{La}$ Quina aval. This study has led to an enhanced understanding of the relationship between Man and his faunal environment.

The faunal spectrum described at La Quina aval is relatively similar to that from other contemporaneous sites: les Rois (Mouton \& Joffroy 1958), La Grotte des Hyènes (Letourneux 2005, 2007), Le Piage (Champagne \& Espitalié 1981), Le Roc-de-Combe (Delpech 1983, Grayson \& Delpech 2008; Soulier \& Mallye 2011), La Ferrassie (Delpech 
1983, 2007), l'abri Castanet (Castel 2011), Isturitz (Bouchud 1951; Normand et al. 2009), Le Flageolet I (Delpech 1983; Delpech, Grayson \& Rigaud 2000) or les Abeilles (Laplace et al. 2006). Only the lynx and the bear, which are relatively common in the sites cited above, are absent here and that could be a consequence of the limited extension of recent excavations. Nonetheless, these species do not appear on the faunal list established by Henri-Martin (1930) for early excavations. He also describes species that we identified in the Dujardin collection; the cave hyena, the lion and the marmot.

As a result of this analysis, the whole hunting spectrum of early Aurignacian prehistoric groups at La Quina aval is recorded. The results of this study appear to be radically different from previous hypotheses as regards the presence of carnivore remains, leporids and the Snowy Owl at this site. All the species, apart from the polecat, were consumed by Aurignacian groups for different purposes (fig. 6). Our results show that the Aurignacian hunting spectrum at la Quina aval is much wider than previously stated, and comprises the wolf, the fox, the hare and the Snowy Owl, as well as medium and large-sized ungulates.

Therefore, although we have no proof of fur conservation, we have demonstrated that wolf, hare and vulpine flesh were consumed. However, the meat mass supplied by the different carcasses remains relatively low. The study of ungulate remains (Soulier 2013) led to the identification of several reindeer, horses and bovines. According to the number of individuals counted for each taxon, the meat mass supplied by ungulates is more than 1,400 kg. As for the species presented in this article, if we exclude the Snowy Owl (as only the claws of this species were present and they could have been used as decorative objects), the corresponding meat mass is estimated at less than $30 \mathrm{~kg}$. Thus the wolf, the fox and the hare represent less than $2 \%$ of the total meat mass transported to the site.

As for the utilitarian aspect, unlike the Henri-Martin collection (Henri-Martin 1930 - pl. 18, fig. 1, 2, 3, 6, 7), the Dujardin material did not yield any carnivore bone remains nor any transformed leporids. Lastly, it is important to recall the presence of numerous perforated carnivore teeth at the site which prove the use of these remains for symbolic and ornamental purposes, although they are beyond the scope of this paper. These pieces comprise two wolf teeth and two fox teeth from the Henri-Martin collection (Henri-Martin 1930 - pl. 19, fig. 1 to 4). In the Germaine Henri-Martin collection, twenty-eight fox teeth, two wolf teeth and one hyena tooth have been described (Granger \& Lévêque 1997). Lastly, the recent excavations revealed five perforated fox teeth. Therefore, all of these taxa represent different activity spheres of the Aurignacian groups in La Quina aval.

Several factors could account for the fact that these anthropogenic marks were only identified recently on the carnivore, leporid and bird of prey remains at this site and also in other archaeological sites:

- Observation techniques. The systematic use of high magnifications (at least $\mathrm{x} 10$ ), provides a better reading of bone surfaces and, where applicable, of the slight modifications of these surfaces. The systematic use of these observation tools will enable us to standardize methods and to record the exploitation of small animals in a more reliable way.

- Preconceived ideas. In recent years, the number of cases of anthropogenic marks on carnivore and small mammal bones has increased continuously. Beforehand, the exploitation of small game by groups of hunter-gatherers was not considered to be energyeffective. Moreover, the presence of carnivore remains in archaeological sites was often 
interpreted as the result of the natural death of these animals, alternating with human occupations. As most of these animals (fox, badger, wolf) could take refuge in the same places as prehistoric groups (rock shelters, caves), it was hardly surprising to unearth their remains there. The example shown by Kruuk (2002) illustrates the extent of alimentary taboos: people who ate carnivore meat without knowing what it was found it tasty but once they discovered what kind of meat it was, they suddenly felt ill. It is thus probable that food taboos partly influenced research.

The reexamination of the carnivore, leporid and bird of prey remains from the site of La Quina aval provides evidence of the exploitation of varied animal resources (for food, utilitarian and symbolic purposes) and presents a new source of information for this period, which is still poorly known (see however, Letourneux 2005, 2007; Soulier 2013; Soulier \& Mallye 2012). The lack of data for carnivore and small game butchery activities at the beginning of the Upper Palaeolithic (cf. supra) probably largely results from an analytical artifact. As for the acquisition of technical elements, only detailed taphonomic and zooarchaeological studies of non-sorted collections will reveal the distinction between hunted and collected animal remains, although it is important to add that these two modalities are not exclusive.

\section{BIBLIOGRAPHY}

ALTUNA J. 2004 - Estudio biométrico de Vulpes vulpes L y Alopex lagopus L. Contribución a su diferenciación en los yacimientos paleolíticos cantábricos. Munibe, n 56, pp. 45-59.

AUGUSTE P. 1995 - Chasse et charognage au Paléolithique moyen : l'apport du gisement de Biache-Saint-Vaast (Pas-De-Calais). Bulletin de la Société Préhistorique Française, 92, n² , pp. 155-167.

AUGUSTE P. 2003 - La chasse à l'Ours au Paléolithique moyen : mythes, réalités et état de la question. In: Patou-Mathis, M. et Bocherens, H. (Eds.), Le rôle de l'environnement dans les comportements des chasseurs-cueilleurs préhistoriques, BAR International Series, pp. 135-142.

BINFORD L. R. 1981 - Bones: Ancient Men and Modern Myths. New-York: Academic Press, 320 p.

BLASCO R. 2008 - Human consumption of tortoises at Level IV of Bolomor Cave (Valencia, Spain). Journal of Archaeological Science, 35, pp. 2839-2848.

BLASCO R. et FERNÁNDEZ-PERIS, J. 2009 - Middle Pleistocene bird consumption at level XI of Bolomor Cave (Valencia, Spain). Journal of Archaeological Science, 36, pp. 2213-2223.

BLASCO R., FERNÁNDEZ-PERIS J. et ROSELL J. 2010a - Several different strategies for obtaining animal ressources in the late Middle Pleistocene: The case of level XII at Bolomor Cave (Valencia, Spain). C. R. Palevol, 9, pp. 171-184.

BLASCO R., ROSELL J., ARSUAGA J. L., BERMÚDEZ DE CASTRO J. M. et CARBONELL E. 2010b - The hunted hunter: the capture of a lion (Panthera leo fossilis) at the Gran Dolina site, Sierra de Atapuerca, Spain. Journal of Archaeological Science, 37, pp. 2051-2060.

BOUCHUD J. 1951 - Étude paléontologique de la faune d'Isturitz. Mammalia, 15, 4, p. 184-203. 
BRATLUND B. 1999a - Anthropogenic factors in the thanatocenose of the last interglacial travertines at Taubach. In: The role of early humans in the accumulation of European lower and middle Palaeolithic bone assemblage, Romisch Garmanisches Zentralmuseum Mainz Monographien, pp. 255-262.

BRATLUND B. 1999b - Taubach revisited. Jahrbuch des Römisch-Germanischen Zentralmuseums Mainz, 46, pp. 61-174.

CASTEL J.-C. 2011 - Archéozoologie de l'Aurignacien de l'Abri Castanet (Sergeac, Dordogne, France) : les fouilles 1994-1998. Revue de Paléobiologie, Genève, 30, 2, p. 783-815.

CHAMPAGNE F. et ESPITALIÉ R. 1981 - Le Piage, Site préhistorique de Lot. Mémoire de la Société Préhistorique Française, 205 p.

CHAUVET G. 1896 - Stations humaines quaternaires de la Charente (Bibliographie et statistiques Fouilles au Ménieux et à La Quina). Bulletins et Mémoires de la société Archéologique et Historique de Charente, 6, pp. 221-351.

CHAUVIÈRE F.-X. et CASTEL J.-C. 2004 - Le statut du Renard à Combe Saunière (Sarliac-sur-l'Isle, Dordogne) et dans le Solutréen de l'Est aquitain. In: Brugal J.-Ph. et Desse, J. (Ed.), Petits animaux et Sociétés humaines. Du complément alimentaire aux ressources utilitaires. XXIVè rencontres internationales d'archéologie et d'histoire d'Antibes, Antibes : Edition APDCA, p. 389-402.

COCHARD D. et BRUGAL J.-Ph. 2004 - Importance des fonctions des sites dans les accumulations paléolithiques de léporidés. In: Brugal, J.-P. et Desse, J. (Ed.), Petits animaux et sociétés humaines. Du complément alimentaire aux ressources utilitaires. XXIVè rencontres internationales d'archéologie et d'histoire d'Antibes, Antibes: APDCA, p. 283-296.

COCHARD D., BRUGAL J.-P., MORIN E. et MEIGNEN L. 2012 - Evidence of small fast game exploitation in the Middle Palaeolithic of Les Canalettes Aveyron, France. Quaternary International, 264, pp. 32-51.

DAVID F. 1997 - Les ours du Châtelperronien de la Grotte du Renne à Arcy-sur-Cure (Yonne). In: Tillet, T. et Binford, L. R. (Ed.), L'Homme et l'Ours. Colloque international Auberives-en-Royan, novembre 1997, Grenoble: ERAULT, pp. 185-192.

DAVID F. 2004 - Note sur l'hyène des cavernes (Crocuta crocuta spelaea G.) dans trois secteurs de la grotte du Renne à Arcy-sur-Cure (Yonne) : Moustérien de la Galerie Schoepflin et de la Rotonde, Châtelperronien du Xc. Revue de Paléobiologie, Genève, 23, 2, pp. 761-769.

DELPECH F. 1983 - Les faunes du Paléolithique supérieur dans le sud-ouest de la France. Editions du CNRS, $453 \mathrm{p}$.

DELPECH F. 2007 - Le grand abri de La Ferrassie, source de réflexion sur la biostratigraphie d'un court moment du Pléistocène. In Arts et cultures de la Préhistoire. Hommage à Henri Delporte. R. Desbrosse et A. Thévenin dir., Editions du CTHS, p. 303-313.

DELPECH F., GRAYSON D.K. et RIGAUD J.-Ph. 2000 - Biostratigraphie et paléoenvironnements du début du Würm récent d'après les grands mammifères de l'abri du Flageolet I (Dordogne, France). Paleo, 12, p. 97-126.

DUJARDIN V. 2001 - Sondages à La Quina aval (Gardes-le-Pontaroux, Charente, France). Antiquité nationales, 33, pp. 21-26.

DUJARDIN V. 2005 - Débitage lamellaire aurignacien à La Quina aval (Gardes-le- Pontaroux) et à la grotte des Renardières (Les Pins, Charente, France). In: Productions lamellaires attribuées à l'Aurignacien : Chaînes opoératoires et perspectives technoculturelles. XIVe congrès de l'UISPP, Liège 2-8 Septembre 2001, Luxembourg: Archéologiques, pp. 273-295. 
DUJARDIN V. 2006 - Châtelperronien et Aurignacien en Poitou-Charentes, l'apport de l'étude La Quina aval à Gardes-le-Pontaroux et des Renardières aux Pins. Bulletin AAPC, 35, pp. 25-39.

DUJARDIN V., ARMAND D., KERVAZO B. et YOUNG T. 1999 - Révision stratigraphique de La Quina Aval (Gardes-le-Pontaroux, Charente). Premiers résultats. Bulletin de la Société Préhistorique Française, 96, 1, pp. 92-94.

DUJARDIN V. et KERVAZO B. 2010 - La Quina, station aval (Charente). In: Buisson- Catil, J. et Primault, J. (Ed.), Préhistoire entre Vienne et Charente. Hommes et sociétés du Paléolithique, Editions Archéologie chauvinoise, pp. 235-243.

DUPONT C. 2001 - Parure en coquillage du site aurignacien de La Quina, station aval (Gardes-lePontaroux, Charente). Antiquité nationales, 33, pp. 27-35.

GOURICHON L. 1994 - Les Harfangs (Nyctea scandiaca L.) du gisement magdalénien du Morin (Gironde). Analyse taphonomique des restes d'un rapace nocturne chassé et exploité par les hommes préhistoriques. Université Lumière-Lyon 2, 180 p.

GRANGER J.-M. et LÉVÊQUE F. 1997 - Parure castelperronienne et aurignacienne: étude de trois séries inédites de dents percées et comparaison. C. R. A. Sci. Paris, Sciences de la Terre et des Planètes, 325, pp. 537-543.

GRAYSON D. K. et DELPECH F. 2008 - The large mammals of Roc de Combe (Lot, France): The Châtelperronian and Aurignacian assemblages. Journal of Anthropological Archaeology, 27, pp. 338-362.

HENRI-MARTIN L. 1925 - Les couches aurignaciennes de La Quina, Station aval, Tranchée Z. L'Anthropologie, 35, pp. 135-138.

HENRI-MARTIN L. 1930 - La Station aurignacienne de La Quina. Bulletin de la société archéologique et historique de la Charente, 20, pp. 1-77.

HENSHILWOOD C. S. 1997 - Identifying the collector: evidence for human processing of the Cape Dune Mole-Rat, Bathyergus suillus, from Blombos Cave, Southern Cape, South Africa. Journal of Archaeological Science, 24, pp. 659-662.

JAUBERT J., HUBLIN J.-J., MCPHERRON S. P., SORESSI M., BORDES J.-G., CLAUD E., COCHARD D., DELAGNES A., MALLYE J.-B., MICHEL A., NICLOT M., NIVEN L., PARK S.-J., RENDU W., RICHARDS M., RICHTER D., ROUSSEL M., STEELE T. E., TEXIER J.-P. et THIÉBAUT C. 2008 - Paléolithique moyen récent et Paléolithique supérieur ancien à Jonzac (Charente-Maritime): premiers résultats des campagnes 2004-2006. In: Jaubert, J., Bordes, J.-G. et Ortega, I. (Ed.), Les sociétés du Paléolithique dans un Grand Sud-Ouest de la France : nouveaux gisements, nouveaux résultats, nouvelles méthodes, Mémoire de la société préhistorique française, pp. 203-243.

KOBY F.-E. 1959a - Les Renards magdaléniens de la Vache. Bulletin de la société Préhistorique de l'Ariège, XIV, pp. 2-10.

KOBY F.-E. 1959b - Contribution au diagnostic ostéologique différentiel de Lepus timidus Linné et L. europaeus Pallas. Verhandlungen der Naturforschenden Gesellschaft in Basel, 70, 1, pp. 19-44.

KOBY F.-E. 1960 - Contribution à la connaissance des lièvres fossiles, principalement de ceux de la dernière glaciation. Verhandlungen der Naturforschenden Gesellschaft in Basel, 71, pp. 149-173.

KRUUK H. 2002 - Hunter and Hunted: Relashionships between Carnivores and People. Cambridge: Cambridge University Press 
LAPLACE G., BARANDIARAN I., SAENZ DE BURUAGA, A. et ALTUNA, J. 2006 - Les Aurignaciens pyrénéens des Abeilles et méditerranéen de Régismont-le-Haut. Analyse typologique et paléontologique. Les Eyzies-de-Tayac : SAMRA

LAROULANDIE V. 2000 - Taphonomie et archéozoologie des Oiseaux en grotte: applications aux sites paléolithiques du Bois-Ragot (Vienne), de Combe Saunière (Dordogne) et de La Vache (Ariège). Thèse de Doctorat, inédit: Université Bordeaux 1, 396.

LETOURNEUX C. 2005 - Étude taphonomique et archéozoologique des niveaux aurignaciens anciens de la grotte des Hyènes (Brassempouy, Landes) «Qui mange quoi ». Archéologie des Pyrénées Occidentales et des Landes, 24, pp. 85-102.

LETOURNEUX C. 2007 - Quelle place pour le Renne dans la subsistance aurignacienne ? Réflexion à partir des quelques exemples de l'Aurignacien ancien. In: Beyries, S. et Vaté, V. (Ed.), Les civilisations du Renne d'Hier et d'Aujourd'hui. Approches ethnohistoriques, archéologiques et anthropologiques, Antibes : APDCA, pp. 1-17.

LLOVERAS, L., MORENO GARCÍA M. et NADAL, J. 2009 - Butchery, Cooking and Human Consumptio Marks on Rabbit (Oryctolagus cuniculus) Bones: An experimental Study. Journal of Taphonomy, 7, 2-3, pp. 179-201.

MALLYE J.-B. 2007 - Les restes de Blaireau en contexte archéologique : Taphonomie, Archéozoologie et éléments de discussion des séquences préhistoriques, Talence : Université Bordeaux 1, $547 \mathrm{p}$.

MALLYE J.-B. 2011 - Réflexion sur le dépouillement des petits carnivores en contexte archéologique: Apport de l'expérimentation. Archaeofauna, 20, pp. 7-25.

MEDINA M. E., TETA P. et RIVERO D. 2012 - Burning damage and small-mammal uman consumption in quebrada del Real 1 (Cordoba, Argentina): an experimental approach. Journal of Archaeological Science, 39, pp. 737-743.

MONCHOT, H. et GENDRON, D. 2010 - Distangling long bones of foxes (Vulpes vulpes and Alopex lagopus) from arctic archaeological sites. Journal of Archaeological Science, 37, pp. 799-806.

MOREL, P. et MÜLLER, W. 1997 - Hauterive-Champréveyres : un campement magdalénien au bord du lac de Neuchâtel. Etude archéozoologique. Neuchâtel: archéologie neuchâteloise, 149 p.

MORIN, E. et LAROULANDIE, V. 2012 - Presumed symbolic use of diurnal raptors by neanderthals. PLOS ONE, 7, 3, pp. e32856.

MOUTON, A. P. et JOFFROY, R. 1958 - Le gisement aurignacien des Rois à Mouthiers (Charente). Paris : Centre National de la Recherche Scientifique (Gallia), 141 p.

MÜNZEL, S. C. et CONARD, N. J. 2004a - Change and continuity in subsistence during the Middle and Upper Palaeolithic in the Arch Valley of Swabia (South-west Germany). International Journal of Osteoarchaeology, 14, pp. 225-243.

MÜNZEL, S. C. et CONARD, N. J. 2004b - Cave bear in Hole Fels in the arch Valley of the Swabian Jura. Revue de Paléobiologie, Genève, 23, 2, pp. 877-885.

NORMAND C., DE BEAUNE S. A., COSTAMAGNO S., DIOT M.-F., HENRY- GAMBIER D., GOUTAS,N., LAROULANDIE,V., LENOBLE A., O'FARRELL M., RENDU W., RIOS GARAIZAR J., SCHWAB,C., TARRIO VINAGRE A., TEXIER J.- P. et WHITE R. 2007 - Nouvelles données sur la séquence aurignacienne de la grotte d'Isturitz (communes d'Isturitz et de Saint-Martin-d'Arberoue ; PyrénéesAtlantiques). In: Evin, J. (Ed.), Congrès du centenaire : Un siècle de construction du discours scientifique en Préhistoire. Volume III... Aux conceptions d'aujourd'hui. Actes du XXVIe Congrès 
Préhistorique de France, Congrès du Centenaire de la Société préhistorique française, Avignon, 21-25 septembre 2004., Paris : Société préhistorique française, pp. 277-293.

PERESANI M., FIORE I., GALA M., ROMANDINI M. et TAGLIACOZZO A. 2011 - Late neandertals and the intentional removal of feathers as evidenced from bird bone taphonomy at Fumane Cave 44 ky B.P., Italy. PNAS, 108, pp. 3888-3893.

POPLIN F. 1976 - Les grands vertébrés de Gönnersdorf, fouille 1968. Wiesbaden: Frantz Steiner Verlag GMBH, 212 p. et $10 \mathrm{pl}$.

ROSENDAHL W. et DRAGA R. 2004 - Homo sapiens neanderthalensis et Panthera leo spelaea - du nouveau à propos du site de Siegsdorf (Chiemgau), Bavière/ Allemagne. Revue de Paléobiologie, 23, 2, pp. 653-658.

SOULIER M.-C. 2013 - Entre alimentaire et technique : exploitation animale aux débuts du Paléolithique supérieur. Stratégies de subsistance et chaînes opératoires de traitement du gibier à Isturitz, La Quina aval, Roc-de-Combe et Les Abeilles. Thèse de doctorat, Université Toulouse 2 Le Mirail, $754 \mathrm{p}$.

SOULIER M.-C. et MALLYE,J.-B. 2012 - Hominid subsistence strategies in the South-West of France: A new look at the early Upper Palaeolithic faunal material from Roc-de-Combe (Lot, France). Quaternary International, 252, pp. 99-108.

STINER M. C. 1994 - Honor among Thieves. A zooarchaeological study of Neandertal ecology. Princeton: Princeton University Press, $447 \mathrm{p}$.

VAL A. et MALLYE,J.-B. 2011 - Small carnivore skining by professionnals: skeletal effects and implications for the European Upper Palaeolithic. Journal of Taphonomy, 9, 4, pp. 221-243.

VERNA C., DUJARDIN V. et TRINKAUS E. 2012 - The Early Aurignacian human remains from La Quina-Aval (France). Journal of Human Evolution, 62, pp. 605-617.

VIGNE J.-D. et MARINVAL-VIGNE M.-C. 1983 - Méthode pour la mise en évidence de la consommation du petit gibier. In : Clutton-Brock, J. et Grigson, C. (Ed.), Animals and Archaeology. 1: Hunters and their prey, pp. 239-242.

VIGNE J.-D., MARINVAL-VIGNE, M.-C., DE LANFRANCHI, F. et WEISS, M.-C. 1981 - Consommation $\mathrm{du}$ « Lapin-rat » (Prolagus sardus Wagner) au Néolithique ancien méditerranéen Abri d'AraguinaSennola (Bonifacio, Corse). Bulletin de la Société Préhistorique Française, 78, 7, pp. 222-224.

VILL P. et MAHIEU E. 1991 - Breakage patterns of human long bones. Journal of Human Evolution, 21, pp. 27-48.

YRAVEDRA J. 2007 - The Taphonomist's corner: Chasing carnivores. Journal of Taphonomy, 5, 2, pp. 135.

\section{ABSTRACTS}

This paper presents the results of a zooarchaeological analysis conducted on the remains of large carnivores and small game from the Early Aurignacian from the site of La Quina aval. This site was excavated successively by Dr. Henri-Martin and her daughter Germaine at the early and midtwentieth century. Recently, the site was re- excavated by Véronique Dujardin. The different excavations yielded a large archaeological sample composed of many faunal remains but also lithic and bone artefact industry, a large number of personal ornament (bones, teeth and shell) as well as several anatomically modern human remains.

Our study focuses on small-game remains found during the last excavation campaign. Our results 
provide several unpublished results. We first offer the first quantification of each taxa in terms of number of identified remains but also in terms of minimal number of individuals.

These data will contribute to define more precisely the paleoenvironment and lead to a better understanding of the paleogeography of the different species. Despite a modest sample size, the evidences of human exploitation were observed on the wolf, the fox, the hare and the snowy owl remains. Our results provide a new vision of the Man's hunting bag during the Early Aurigacian in Charente. The butchery processes are discussed and the economical status of each game is proposed.

Dans cet article, nous présentons les résultats d'une analyse archéozoologique qui a porté sur les restes de grands carnivores et de petits vertébrés du gisement de La Quina aval (Charente, France). Ce gisement a été fouillé par le docteur Henri-Martin puis par sa fille au début et au milieu du XXè siècle. La dernière campagne de fouille dirigée par Véronique Dujardin remonte à la fin du siècle dernier. Le gisement a livré les témoins d'une industrie lithique et osseuse attribuable à l'Aurignacien ancien, un grand nombre d'objets de parure ainsi que des restes d'Homme anatomiquement moderne.

Notre étude a porté sur les restes trouvés lors de la dernière campagne de fouille. Nos résultats apportent plusieurs éléments inédits. Ils livrent tout d'abord une quantification de chaque taxon en nombre de restes mais aussi en nombre d'individus documentant ainsi la répartition des espèces à cette période. De plus, malgré un échantillon de taille modeste, les indices d'une exploitation du Loup, du Renard, du Lièvre et du Harfang permettent d'élargir le tableau de chasse des hommes de l'Aurignacien ancien de cette région et de percevoir les modalités d'exploitation de ces nouveaux gibiers.

\section{INDEX}

Mots-clés: Aurignacien ancien, La Quina aval, archéozoologie, carnivores, petits gibiers, boucherie

Keywords: Early Aurignacian, La Quina aval, Zooarchaeology, carnivores, small game, butchery

\section{AUTHORS}

\section{JEAN-BAPTISTE MALLYE}

Université Bordeaux 1 PACEA UMR 5199 CNRS,Avenue des Facultés, FR-33405 Talence Cedex -

jb.mallye@pacea.u-bordeaux1.fr

\section{MARIE-CÉCILE SOULIER}

Université Toulouse 2 - Le Mirail TRACES-UMR 5608 CNRS, Maison de la Recherche 5, allées Antonio Machado, FR-31058 Toulouse cedex 9 - mariecsoulier@gmail.com

\section{VÉRONIQUE LAROULANDIE}

Université Bordeaux 1 PACEA UMR 5199 CNRS,Avenue des Facultés, FR-33405 Talence Cedex v.laroulandie@pacea.u-bordeaux1.fr 